\title{
Steam gasification of waste tyre: Influence of process temperature on yield and product composition
}

\author{
Sabrina Portofino ${ }^{\mathrm{a}, *}$, Antonio Donatelli ${ }^{\mathrm{b}}$, Pierpaolo Iovane ${ }^{\mathrm{b}}$, Carolina Innella ${ }^{\mathrm{b}}$, Rocco Civita ${ }^{\mathrm{b}}$, \\ Maria Martino $^{\mathrm{b}}$, Domenico Antonio Matera ${ }^{\mathrm{b}}$, Antonio Russo ${ }^{\mathrm{b}}$, Giacinto Cornacchia ${ }^{\mathrm{b}}$, Sergio Galvagno ${ }^{\mathrm{a}}$ \\ ${ }^{a}$ UTTP NANO - C.R. ENEA Portici, P.le E. Fermi, 1 Loc. Granatello, 80055 Portici (NA), Italy \\ ${ }^{\mathrm{b}}$ UTTTRI RIF - C.R. ENEA Trisaia, SS Jonica 106, km 419.5, 75026 Rotondella (MT), Italy
}

\section{A R T I C L E I N F O}

\section{Article history:}

Received 7 February 2012

Accepted 30 May 2012

Available online 30 June 2012

\section{Keywords:}

Steam gasification

Waste tyres

Continuous furnace

Syngas

\begin{abstract}
A B S T R A T
An experimental survey of waste tyre gasification with steam as oxidizing agent has been conducted in a continuous bench scale reactor, with the aim of studying the influence of the process temperature on the yield and the composition of the products; the tests have been performed at three different temperatures, in the range of $850-1000{ }^{\circ} \mathrm{C}$, holding all the other operational parameters (pressure, carrier gas flow, solid residence time). The experimental results show that the process seems promising in view of obtaining a good quality syngas, indicating that a higher temperature results in a higher syngas production (86 wt\%) and a lower char yield, due to an enhancement of the solid-gas phase reactions with the temperature. Higher temperatures clearly result in higher hydrogen concentrations: the hydrogen content rapidly increases, attaining values higher than $65 \% \mathrm{v} / \mathrm{v}$, while methane and ethylene gradually decrease over the range of the temperatures; carbon monoxide and dioxide instead, after an initial increase, show a nearly constant concentration at $1000{ }^{\circ} \mathrm{C}$. Furthermore, in regards to the elemental composition of the synthesis gas, as the temperature increases, the carbon content continuously decreases, while the oxygen content increases; the hydrogen, being the main component of the gas fraction and having a small atomic weight, is responsible for the progressive reduction of the gas density at higher temperature.
\end{abstract}

(c) 2012 Elsevier Ltd. All rights reserved.

\section{Introduction}

The disposal of waste tyres represents a relevant problem within the waste management strategy of the European Community: the world production amounts to 7 millions of tons (according to the European Tyre Recycling Association, Report 2008), 3 million of which are generated in Europe, that is $2 \%$ of total solid waste production, and even today the final destination of nearly 65$70 \%$ of such an amount is the landfill, with the consequent loss of high added value materials (Mui et al., 2004) and the relevant environmental impact.

Attempts on waste tyre reuse as solid fuel are largely documented: waste tyres have been used as principal or secondary fuel source in the production of steam, electricity, cement, lime, paper, steel and into the incineration of garbage; however these experiences have been severely limited by the scarce market demand and by the overall operational costs of the plants (Sharma et al., 1998). Anyway, it is well known that tyres possess high volatile and low ash contents with a heating value greater than that of coal and biomass. These properties make them an ideal material for

\footnotetext{
* Corresponding author. Tel.: +39 0817723579; fax: +39 0817723550.

E-mail address: sabrina.portofino@enea.it (S. Portofino).
}

thermal processes like pyrolysis and gasification (Kiran et al., 2000; Morris and Waldheim, 1998; Bridgwater, 2003), that, unlike combustion, convert the intrinsic chemical energy of a carbon-rich material in valuable by-products (Leung et al., 2002; Zabaniotou and Stavropoulos, 2003; Malkow, 2004). Among the thermal technologies, the gasification of waste tyres seems to be attractive since the gaseous fuel derived from the process can be stored, transported and easily fueled for existing boilers and combustors with little modifications (Belgiorno et al., 2003; Franco and Giannini, 2005). Another alternative consists in conveying the syngas in a fuel cell, thus improving the overall efficiency of the process (McKendry, 2002; Chaudhari et al., 2003); in a modern fuel cell, such as a molten carbonate type, a steady stream of hydrogen is required as fuel and for this reason the syngas must be adequately cleaned from trace contaminants and the composition must be properly upgraded (Lobachyov and Richter, 1998; Wu et al., 2006). In any case at moment the experiences are limited to bench or pilot scale studies (Galvagno et al., 2002; Donatelli et al., 2010).

Most part of the literature data on the waste tyre gasification are collected in fluidized bed reactors and using air as oxidizing agent, while data concerning other experimental designs are hardly found. Within this framework, the present study reports the results of an experimental survey of waste tyre gasification, 
conducted with steam on a bench-scale continuous rotating reactor, with the final goal of determining the influence of the process temperature on the yields and the composition of the products.

\section{Materials and methods}

\subsection{Materials}

The waste tyres used for the experimental work were supplied by an Italian producer (Elastrade). Granulated tyre samples of maximum $6 \mathrm{~mm}$ mean diameter were selected and kept at ambient conditions. About $250 \mathrm{~g}$ of material was used for each test.

\subsection{Apparatus}

The schematic diagram of the experimental device is reported in Fig. 1. The gasification tests were conducted on a bench scale apparatus designed and assembled at ENEA "Portici" Research Center.

Rotary kilns and similar equipments have not been widely used for gasification treatment, meanwhile, they offer such flexible adjustments configurations to be able to achieve an easy management of the process even with a highly heterogeneous material (Galvagno et al., 2006).

The materials was loaded in a feeder hopper of maximum capacity $5 \mathrm{dm}^{3}$, with an airtight closure system and a mechanical stirrer, which was fitted with a screw device operating over the whole length of the equipment, heated zone included. The screw rotation speed was ruled by an inverter. The reactor was enclosed in a split furnace, Carbolite HST 12/600, and externally heated. Due to this configuration, the material enters the reactor from the hopper and rolls down the length of the kiln. The steam for the tests was produced by injecting water into the reactor at controlled rate (with a peristaltic pump) through a series of spatially distributed holes located on the central screw feeder. The solid residue was continuously discharged into a tank at the outlet of the reactor while the process gas was headed for the cleaning system.

The cleaning system firstly consists of an ice jacketed condenser trap that cooled the gas from the reactor further to room temperature and removed the most part of the oil particles from the gaseous products, together with the excess steam; subsequently first the gas was filtered by a ceramic wool filter, for the soot and the oil removal, then it bubbled into a $1 \mathrm{M} \mathrm{NaOH}$ solution, that fulfilled a basic scrubber for the acid removal; an additional filter prevented any further charcoal transport; the extent of the products condensation throughout the cleaning system was detected by weight difference.
In any test, nitrogen was used as carrier gas, to create safety working conditions. Before starting the gasification experiments, the initial nitrogen flow rate was maintained at $1.5 \mathrm{dm}^{3} \mathrm{~min}^{-1}$ to completely purge the system till the prescribed process temperature was reached.

\subsection{Characterization}

A thermogravimetric system (TA Instruments TGA 2950), coupled with a Thermo Optek FTIR spectrometer, was used to set up the thermal process and characterize the waste tyre samples, with respect to proximate analysis (Mayoral et al., 2001) (that is, moisture, volatile matter, fixed carbon, and ash content of the material); thermogravimetric curves were recorded at different heating rates, using pure nitrogen as inert purge gas, at constant flow rate of $100 \mathrm{~cm}^{3} \mathrm{~min}^{-1}$.

Proximate analyses were verified according to the CTI (Italian Technical Committee) Standard 2/156.6 and CTI 2/156.7 (volatile content is calculated by burning the sample in a closed metallic pot at $850^{\circ} \mathrm{C}$ for nearly $7 \mathrm{~min}$; ash residue is further burned at $750{ }^{\circ} \mathrm{C}$ till a constant weight is obtained; the fixed carbon is obtained by the difference). The organic matter is the sum of the volatile fraction plus the fixed carbon, on dry basis.

Ultimate analysis was obtained with a Thermo Quest model EA 1110 analyzer. Such analysis gives the weight percent of carbon, hydrogen, nitrogen, and sulfur in the samples simultaneously; afterward, the determination of the oxygen content can be obtained by difference.

The heating value of the material was estimated using a bomb calorimeter (model IKA C5000) in adiabatic modality. Flue gas from the combustion chamber was allowed to pass through a sampling bottle filled with a $\mathrm{NaHCO}_{3} / \mathrm{Na}_{2} \mathrm{CO}_{3}$ buffer solution, to be further analyzed for chlorine determination.

On-line gas analysis was conducted with a gas chromatograph (Agilent model 3000A) that was able to provide precise analysis of the principal gas components $\left(\mathrm{H}_{2}, \mathrm{O}_{2}, \mathrm{~N}_{2}, \mathrm{CO}, \mathrm{CO}_{2}, \mathrm{CH}_{4}, \mathrm{C}_{2} \mathrm{H}_{4}\right.$, $\mathrm{C}_{2} \mathrm{H}_{6}$ ) within no more than 2-3 min. The instrument was equipped with two different columns that were working in parallel (Molsieve 5A e Poraplot Q) and used a thermal conductivity detector (TCD); the carrier gas was argon in all analyses.

\subsection{Gasification tests}

The steam gasification of tyres were performed in a series of trials at different processing temperatures, in the range of 850 $1000^{\circ} \mathrm{C}$, holding all the other operational parameters constant (screw rotational speed, water feeding rate, carrier gas flux), as

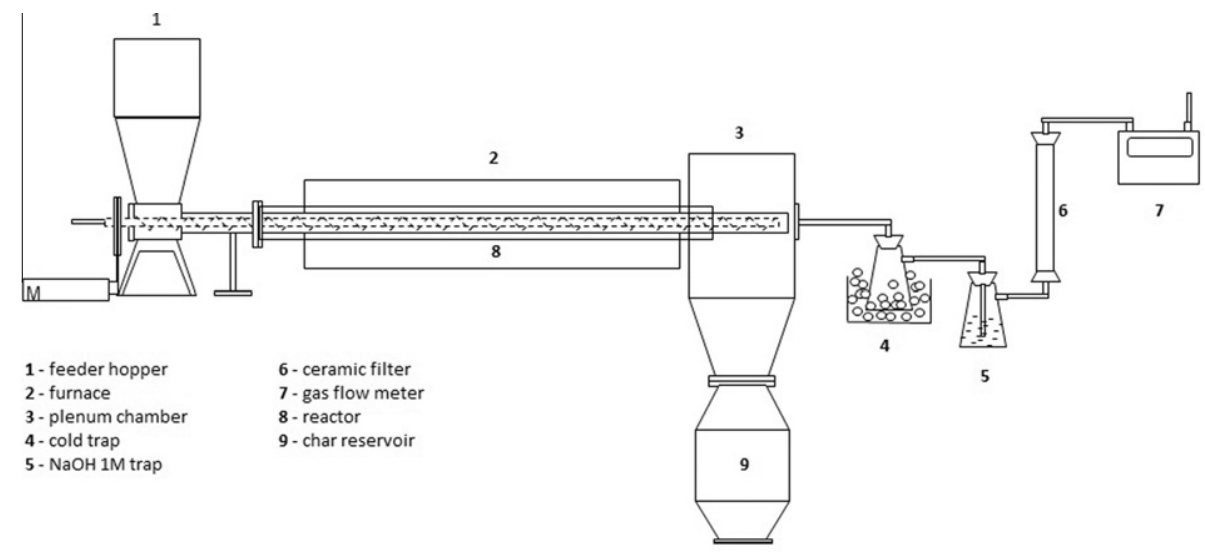

Fig. 1. Bench scale gasification system. 
reported in Table 1; such parameters, in turn, fix the solid and the gas residence times. Experiments set-up and calculations methods have been already discussed in a previous work (Galvagno et al., 2009; Sullivan et al., 1927).

The gas residence time $\left(t_{\mathrm{g}}\right)$ is calculated assuming an ideal behavior, according to the following equation:

$T_{\mathrm{g}}=V / \mathrm{F}_{T}$

where $V$ is the heating zone volume and $F_{\mathrm{T}}$ is the flux at the processing temperature.

The influence of the temperature on the process has been studied through the comparison of the different trials, with respect to the yields, to the chemical composition and to the mass balances of the main components of the process. In this respect, it is important to remark that a large amount of soot was produced during the tests, which was appreciably reduced only at high temperature $\left(1000^{\circ} \mathrm{C}\right)$; consequently, to prevent the plugging of the pipes, a severe filtration with ceramic wool was necessary, which rendered extremely difficult the separation between tar and soot. For this reason, both fractions were collected together and coded as "oil". The application of an in bed or ex bed catalytic upgrading could improve the process. This issue has been already discussed in a previous work (Portofino et al., 2011).

\section{Results and discussion}

\subsection{Characterization of waste tyres}

According to the decomposition profile (Fig. 2), the thermal decomposition of the waste tyre starts at about $220^{\circ} \mathrm{C}$ and is practically complete at $\approx 600{ }^{\circ} \mathrm{C}$. The decomposition occurs through a series of peaks which account for the simultaneous degradation of the main components of the tyre, principally natural rubber (NR), styrene-butadiene rubber (SBR) and butadiene rubber (BR) (Sułkowski et al., 2004). The maximum degradation rates are located in the temperature range of $375^{\circ} \mathrm{C}$ for NR, $445^{\circ} \mathrm{C}$ for SBR and $465^{\circ} \mathrm{C}$ for BR.

Fig. 3 shows the FTIR analysis of the volatile products; relevant spectra have been selected from the series collected by combined TGA/FTIR experiment. The analysis revealed the presence of the compounds normally ascribed to the decomposition of the single elastomers present in the tyre (Sułkowski et al., 2004; Williams and Besler, 1995; Leung and Wang, 1998), that are mainly branched alkenes (methyl-butylene/pentene/hexane/heptene), toluene and benzene, and their corresponding degradation products (methane, carbon monoxide, ethylene, acetylene, etc.), under pyrolysis conditions (Table 2). A detailed analysis of FTIR signals, together with MS signals was developed in another work (Galvagno et al., 2007).

Table 3 reports the proximate and ultimate analysis of the tyres. Proximate analysis is a standard compositional analysis conducted for the determination of moisture, volatile matter, fixed carbon and ash of compounds and it is used to establish the rank of coals, to show the ratio of combustible to incombustible constituents, etc. While the volatile matter (often comprising the moisture) generally accounts for the fraction that is evolved during the thermal

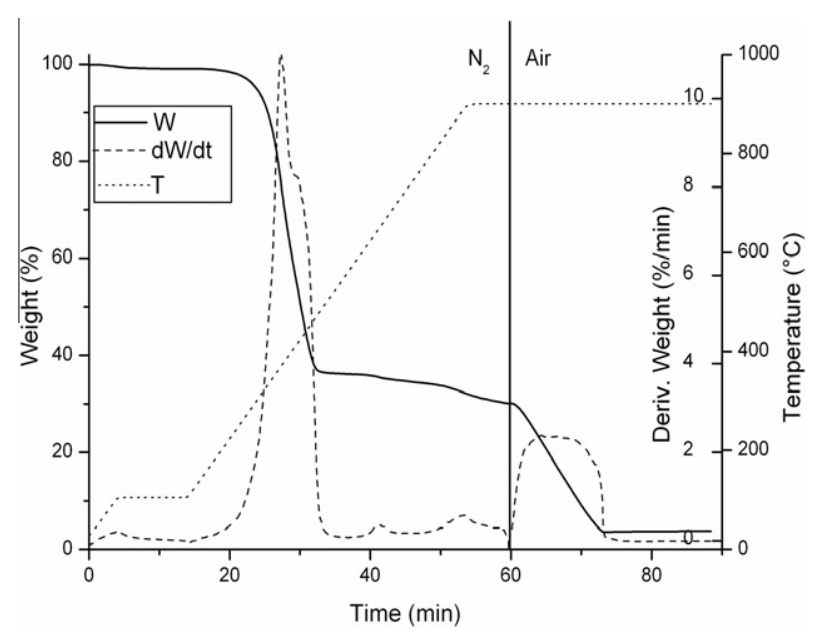

Fig. 2. Waste tyre thermogram, showing a ramp at $10{ }^{\circ} \mathrm{C} \mathrm{min}^{-1}$ in $\mathrm{N}_{2}$ atmosphere to $900^{\circ} \mathrm{C}$, followed by air combustion.

decomposition, the fixed carbon, together with the ash, represents the theoretical solid residue (the char fraction) of a possible pyrolysis/gasification process.

In this respect, the data show that the starting material, on a dry base, is shared for more than $65 \%$ into the volatile fraction and for $26 \%$ into the solid residue, together with the ash $\left(6.8 \%_{\mathrm{w}}\right)$. Accordingly, the ultimate analysis shows a significant sulfur amount, nearly $2 \%_{\mathrm{w}}$, due to the vulcanization process of the rubber, and a very high carbon content $\left(77.3 \%_{\mathrm{w}}\right)$. The material has a high heating value, while there is no evidence of chlorine.

Table 4 reports the yields of the process fractions (char, oil, and gas) at different temperatures: the data show that the mass balance exceeds $100 \%$, because of the introduction of the steam (Wei et al., 2007). Furthermore, as expected, rising the temperature, the gas yield progressively increases while char and oils yields decrease; the temperature effect mainly affects the condensable fraction more than the solid residue indicating an increase of the secondary cracking reactions in vapor phase (Encinar et al., 2002; Morf et al., 2002).

In regard to the gas fraction, the principal components (apart from nitrogen, which was used as the carrier gas), detected over the different trials and reported in Fig. 4, were $\mathrm{H}_{2}, \mathrm{CH}_{4}, \mathrm{CO}, \mathrm{CO}_{2}$, and small quantities of some hydrocarbons, such as ethane, ethylene, and acetylene.

Higher temperatures clearly result in higher hydrogen concentrations; the hydrogen content rapidly increases, attaining values higher than $65 \%$, while methane and ethylene gradually decrease over the range of the temperatures; carbon monoxide and dioxide instead, after an initial increase, show a nearly constant concentration at $1000{ }^{\circ} \mathrm{C}$.

This situation is probably dependent on the more favorable thermal cracking and steam reforming reactions that were caused by higher temperatures, which result in the major extensions of the secondary cracking reactions into the gas fraction (Turn et al., 1998; Lin et al., 2004).

Table 1

Operational and process parameters.

\begin{tabular}{|c|c|c|c|c|c|c|}
\hline Test & $\begin{array}{l}\text { Temp. } \\
\left({ }^{\circ} \mathrm{C}\right)\end{array}$ & $\begin{array}{l}\text { Pressure } \\
\text { (bar) }\end{array}$ & $\begin{array}{l}\text { Carrier gas flow }\left(\mathrm{N}_{2}\right) \\
(1 / \mathrm{min})\end{array}$ & Steam/tyre ratio & $\begin{array}{l}\text { Solid residence time } \\
(\mathrm{min})\end{array}$ & $\begin{array}{l}\text { Gas residence time } \\
\text { (s) }\end{array}$ \\
\hline $\mathrm{T} 1$ & 850 & 1 & 1.0 & 2 & 100 & 6.2 \\
\hline $\mathrm{T} 2$ & 925 & 1 & 1.0 & 2 & 100 & 5.7 \\
\hline T3 & 1000 & 1 & 1.0 & 2 & 100 & 5.3 \\
\hline
\end{tabular}




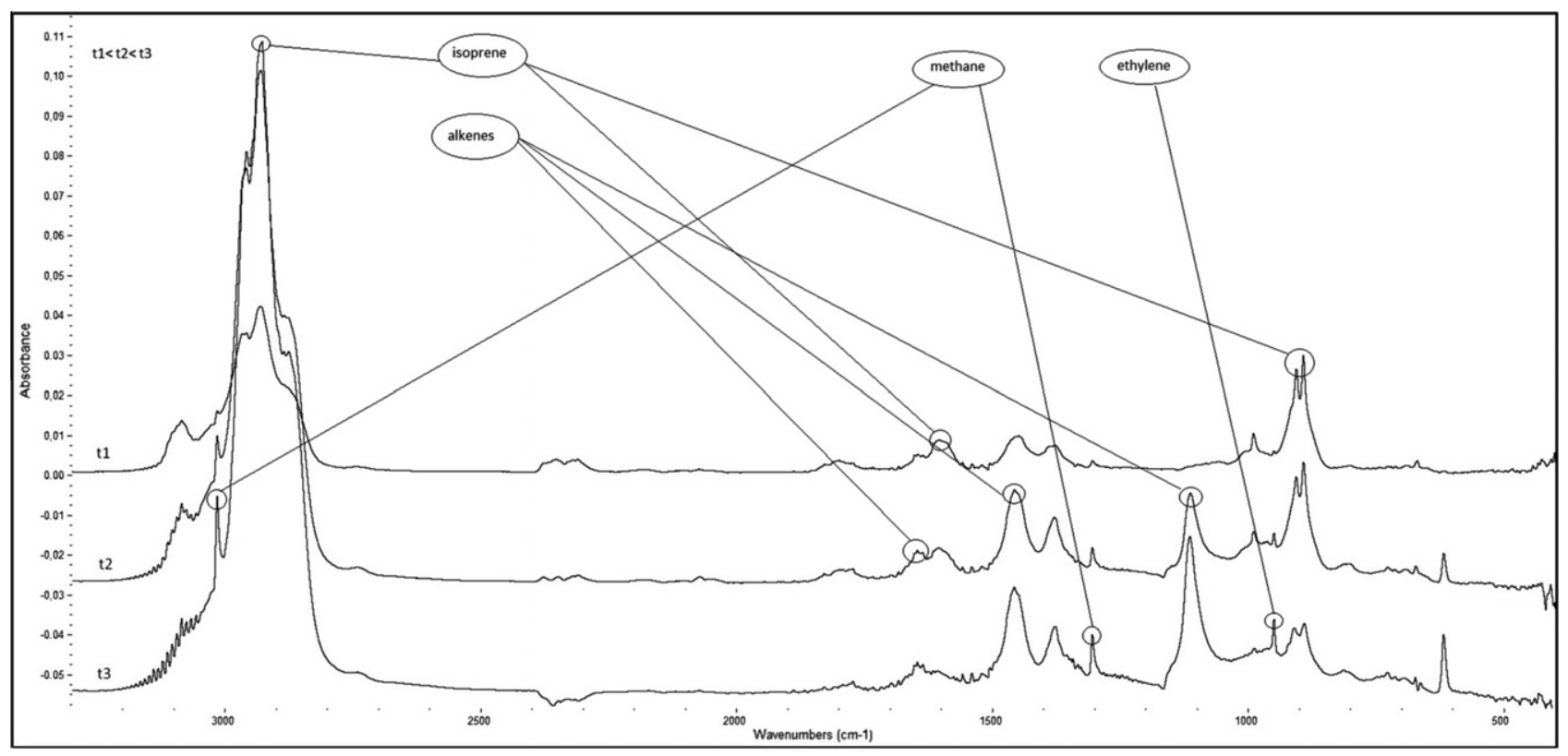

Fig. 3. FTIR spectrum of evolved gas.

Table 2

Main FTIR signals of compounds evolved by elastomers pyrolysis.

\begin{tabular}{lll}
\hline Elastomer & Compound & FTIR signals $\left(\mathrm{cm}^{-1}\right)$ \\
\hline NR & 2-Methyl-1,3- & $3101-2986-2957-1801-1603-1443-991-$ \\
& butadiene & $905-893$ \\
& 2-Methyl-1-butene & $3082-2974-2899-1661-1458-1077-890$ \\
& 1-Pentene & $3085-2966-1637-1456-999-913$ \\
& 1-Hexene & $3083-2936-1639-1453-994-917$ \\
& 2-Methyl-1-pentene & $3082-2968-1649-1455-1385-891$ \\
& 2-Methyl-1-hexene & $3082-2969-2939-1651-1458-1383-890$ \\
BR & Butadiene & $3018-1604-1012-909$ \\
& 4-Vynil- & $3086-3034-2937-2854-1644-1442-915$ \\
& cyclohexene & \\
Cyclohexene & 2935 \\
SBR & Toluene & $3042-2933-1605-1497-1029-728-693$ \\
& Styrene & $3080-3027-1634-1497-1421-986-909-$ \\
& Benzene & $775-695$ \\
& Ethylbenzene & $3047-1482-1042-672$ \\
& & $3082-2968-1649-1455-1385-891$ \\
\hline
\end{tabular}

Table 3

Proximate and ultimate analysis of starting material.

\begin{tabular}{llll}
\hline & Weight $^{\mathrm{a}}($ wt $\%)$ & & Weight $^{\mathrm{a}}$ (wt\%) \\
\hline $\mathrm{C}$ & 77.3 & Volatile & 67.7 \\
$\mathrm{H}$ & 6.2 & Fixed C & 25.5 \\
$\mathrm{~N}$ & 0.6 & Ash & 6.8 \\
$\mathrm{~S}$ & 1.8 & & \\
$\mathrm{O}$ & 7.1 (by difference) $^{3}$ & & \\
Density & $0.8 \mathrm{~g} / \mathrm{dm}^{3}$ & \\
\hline
\end{tabular}

a On dry basis.

Table 4

Fractional yield.

\begin{tabular}{llll}
\hline Test & Char yield $(w t \%)$ & Oil $^{\mathrm{a}}$ yield $(w t \%)$ & Gas yield $(w t \%)$ \\
\hline T1 & 43.4 & 27.0 & 34.7 \\
T2 & 38.5 & 21.8 & 64.5 \\
T3 & 33.3 & 5.3 & 85.9
\end{tabular}

a Oil = condensable fraction of tar and soot
Eqs. (1) and (2) represent the steam cracking reactions for methane, the most aboundant hydrocarbon in the mixture; similar reactions can be written for the other components.

$\mathrm{CH}_{4}+\mathrm{H}_{2} \mathrm{O} \rightarrow \mathrm{CO}+3 \mathrm{H}_{2} \quad \Delta H_{298 \mathrm{~K}}=206.1 \mathrm{~kJ} / \mathrm{mol}$

$\mathrm{CH}_{4}+2 \mathrm{H}_{2} \mathrm{O} \rightarrow \mathrm{CO}_{2}+4 \mathrm{H}_{2} \quad \Delta \mathrm{H}_{298 \mathrm{~K}}=164.6 \mathrm{~kJ} / \mathrm{mol}$

Generally hydrocarbons reactions could be expressed as

$\mathrm{C}_{\mathrm{n}} \mathrm{H}_{\mathrm{m}}+2 \mathrm{nH}_{2} \mathrm{O} \rightarrow(2 \mathrm{n}+\mathrm{m} / 2) \mathrm{H}_{2}+\mathrm{nCO}_{2} \quad \Delta \mathrm{H}_{298 \mathrm{~K}}>0$

Carbon monoxide and carbon dioxide abundance is influenced by the contemporary effect of the Eqs. (5)-(7):

$$
\begin{aligned}
& \mathrm{CO}+\mathrm{H}_{2} \mathrm{O} \rightarrow \mathrm{CO}_{2}+\mathrm{H}_{2} \quad \Delta H_{298 \mathrm{~K}}=-41.2 \mathrm{~kJ} / \mathrm{mol} \\
& \mathrm{C}+\mathrm{CO}_{2} \rightarrow 2 \mathrm{CO} \quad \Delta H_{298 \mathrm{~K}}=172.5 \mathrm{~kJ} / \mathrm{mol} \\
& \mathrm{C}+\mathrm{H}_{2} \mathrm{O} \rightarrow \mathrm{CO}+\mathrm{H}_{2} \quad \Delta H_{298 \mathrm{~K}}=131.3 \mathrm{~kJ} / \mathrm{mol}
\end{aligned}
$$

Thermodynamical data show that the water-gas shift reaction (5), is less important at higher temperature, while the heterogeneous reactions, Boudouard reaction (6) and the carbon steam gasification (7) act on the carbon residue. Such reactions as a whole, together with the secondary cracking tar reactions, are the main factors responsible for the increase in hydrogen (Boroson et al., 1989).

Table 5 reports the elemental composition (carbon, hydrogen and oxygen) of the synthesis gas, which shows that, as the temperature increases, the carbon content continuously decreases, while the oxygen content increases; the hydrogen, being the main component of the gas fraction and having a small atomic weight, is responsible for the progressive reduction of the gas density at higher temperature.

Furthermore, raising the temperature, the heating value decreases from $25.1 \mathrm{MJ} / \mathrm{m}^{3}$ to $14.6 \mathrm{MJ} / \mathrm{m}^{3}$; however, on the other hand, the energy content of the total gas shows a remarkable increase (from $16.8 \mathrm{MJ} / \mathrm{kg}$ of feed to $25.0 \mathrm{MJ} / \mathrm{kg}$ of feed).

As reported in Table 6, the higher temperatures, together with the presence of the steam, strongly influence the total volume of the gas produced, and with an increase in temperature from $850{ }^{\circ} \mathrm{C}$ to $1000^{\circ} \mathrm{C}$, the gas volume per kilogram of feeding definitely triples. This aspect becomes more significant considering 


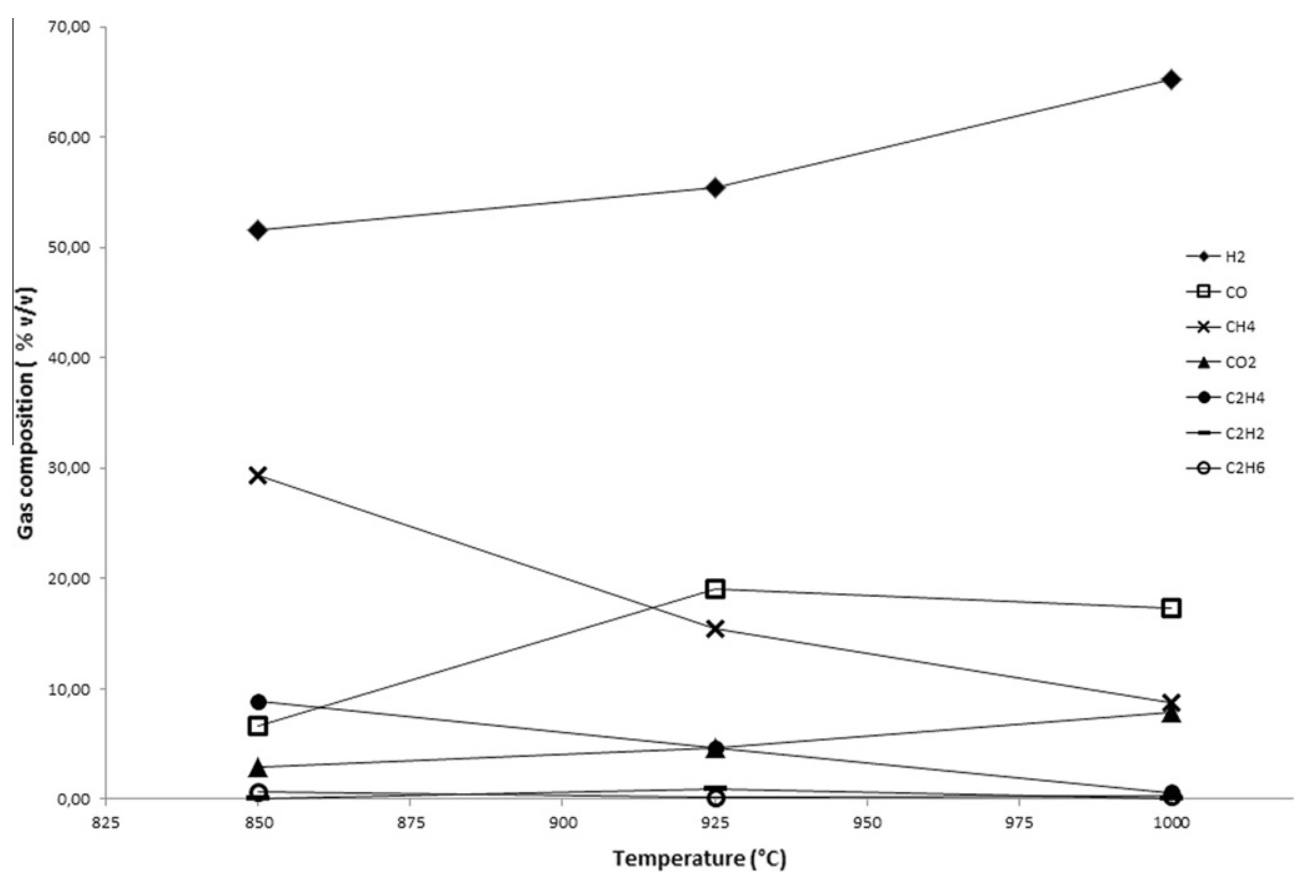

Fig. 4. Gas composition versus process temperature.

the separate contribution of the single components of the gas mixture: as it would be expected, hydrogen mainly affects the gas production at higher temperature, reaching a value of $1.12 \mathrm{~m}^{3} / \mathrm{kg}$ at $1000{ }^{\circ} \mathrm{C}$, over a total production of $1.70 \mathrm{~m}^{3} / \mathrm{kg}$. The progressive increase of hydrogen and carbon monoxide production is a clear indication of the major extension of the secondary cracking reactions; moreover, the methane behavior, that is the gradual decrease at higher temperature, is a compromise between the improved global gas production and the contemporary extended secondary cracking mechanisms.

Table 7 reports the proximate analysis of the char fraction at different processing temperatures; in comparison with the starting material, the char has a lower volatile content and a very high fixed carbon content in each test. It has to be noted that the fixed carbon slowly decreases with the temperature while the ash content grows, due to the effect of the reaction (7), which lowers the char yield (see Table 3 ) and increases the ash amount onto the solids residue (Chaudhari et al., 2001; Braekman-Danheux et al., 1998). In this regards, the appreciable organic content suggests its further exploitation as a secondary row material (carbon source, active carbon, etc.) (Nakagawa et al., 2002; González et al., 2006; Rodriguez-Reinoso et al., 1995; Ko et al., 2004).

The conversion data are reported in the last column of the table for each test; the values have been calculated according to the following formula:

Table 5

Gas characterization.

\begin{tabular}{|c|c|c|c|}
\hline \multirow[t]{2}{*}{ Parameter } & \multicolumn{3}{|l|}{ Value } \\
\hline & $\mathrm{T} 1$ & $\mathrm{~T} 2$ & T3 \\
\hline C (wt\%) & 60.2 & 48.9 & 38.1 \\
\hline $\mathrm{H}(w t \%)$ & 22.5 & 16.8 & 15.1 \\
\hline $\mathrm{O}(\mathrm{wt} \%)$ & 17.4 & 34.3 & 48.9 \\
\hline \multicolumn{4}{|l|}{ Gas heating value } \\
\hline GHV (MJ/m³ gas) & 25.1 & 19.1 & 14.6 \\
\hline GHV (MJ/kg of feed) & 16.8 & 22.0 & 25.0 \\
\hline Gas density at n.c. $\left(\mathrm{kg} / \mathrm{m}^{3}\right)$ & 0.5 & 0.6 & 0.5 \\
\hline
\end{tabular}

Table 6

Gas composition at different temperature.

\begin{tabular}{lllllllll}
\hline Test & $\begin{array}{l}\mathrm{H}_{2} \\
\mathrm{~m}^{3} / \mathrm{kg}\end{array}$ & $\begin{array}{l}\mathrm{CO} \\
\mathrm{m}^{3} / \mathrm{kg}\end{array}$ & $\begin{array}{l}\mathrm{CO}_{2} \\
\mathrm{~m}^{3} / \mathrm{kg}\end{array}$ & $\begin{array}{l}\mathrm{CH}_{4} \\
\mathrm{~m}^{3} / \mathrm{kg}\end{array}$ & $\begin{array}{l}\mathrm{C}_{2} \mathrm{H}_{4} \\
\mathrm{~m}^{3} / \mathrm{kg}\end{array}$ & $\begin{array}{l}\mathrm{C}_{2} \mathrm{H}_{2} \\
\mathrm{~m}^{3} / \mathrm{kg}\end{array}$ & $\begin{array}{l}\mathrm{C}_{2} \mathrm{H}_{6} \\
\mathrm{~m}^{3} / \mathrm{kg}\end{array}$ & $\begin{array}{l}\text { Total } \\
\mathrm{m}^{3} / \mathrm{kg}\end{array}$ \\
\hline $\mathrm{T} 1$ & 0.34 & 0.04 & 0.02 & 0.20 & 0.06 & 0.00 & 0.00 & 0.70 \\
$\mathrm{~T} 2$ & 0.64 & 0.22 & 0.05 & 0.18 & 0.05 & 0.01 & 0.00 & 1.20 \\
$\mathrm{~T} 3$ & 1.12 & 0.30 & 0.13 & 0.15 & 0.01 & 0.00 & 0.01 & 1.70 \\
\hline
\end{tabular}

conversion $=$ reacted organic matter/total organic matter

Holding all the other operational parameters constant, the conversion degree of the whole steam gasification process increases with the temperature.

With respect to the elemental composition (Table 8), the data show a gradual decrease in the carbon content at higher temperature, while the hydrogen content remains nearly constant. Sulfur content ranges from $1 \%$ to $2 \%$.

Figs. $5 \mathrm{a}, 5 \mathrm{~b}$ and $5 \mathrm{c}$ show for each test the distribution of carbon, hydrogen and sulfur on the different process fractions and the corresponding mass balance, with respect to their initial amount in the feed. Considering the nature of the oil fraction (tar + soot), it was impossible to perform the ultimate analysis on this fraction; for this reason its contribution was calculated by difference together with the gas cleaning sorption $\left(\mathrm{CO}_{2}\right.$ and $\mathrm{COS}$ in the scrubber). This contribution was collected as "other" in the figures. As reported, as far as the hydrogen is concerned, the minus sign expresses an over-difference that is due to the introduction of the steam, which is responsible for the increase of the hydrogen content. Carbon is appreciably present in each fraction; however, at higher temperature, the gas fraction is progressively enriched in

Table 7

Char proximate analysis.

\begin{tabular}{lllll}
\hline Test & Volatile (wt\%) & Fixed carbon (wt\%) & Ash (wt\%) & Conversion \\
\hline T1 & 3.10 & 78.90 & 18.00 & 0.62 \\
T2 & 4.39 & 77.51 & 18.10 & 0.66 \\
T3 & 5.65 & 71.99 & 21.92 & 0.72 \\
\hline
\end{tabular}


Table 8

Char ultimate analysis.

\begin{tabular}{llllll}
\hline Test & $\mathrm{C}(\mathrm{wt} \%)$ & $\mathrm{H}(\mathrm{wt} \%)$ & $\mathrm{N}(\mathrm{wt} \%)$ & $\mathrm{S}(\mathrm{wt} \%)$ & $\mathrm{O}^{\mathrm{a}}$ (wt\%) \\
\hline T1 & 77.02 & 1.74 & 0.17 & 0.88 & 2.19 \\
T2 & 76.23 & 1.88 & 0.19 & 1.12 & 2.48 \\
T3 & 71.62 & 1.98 & 0.14 & 1.60 & 2.85 \\
\hline
\end{tabular}

a Calculated by difference.

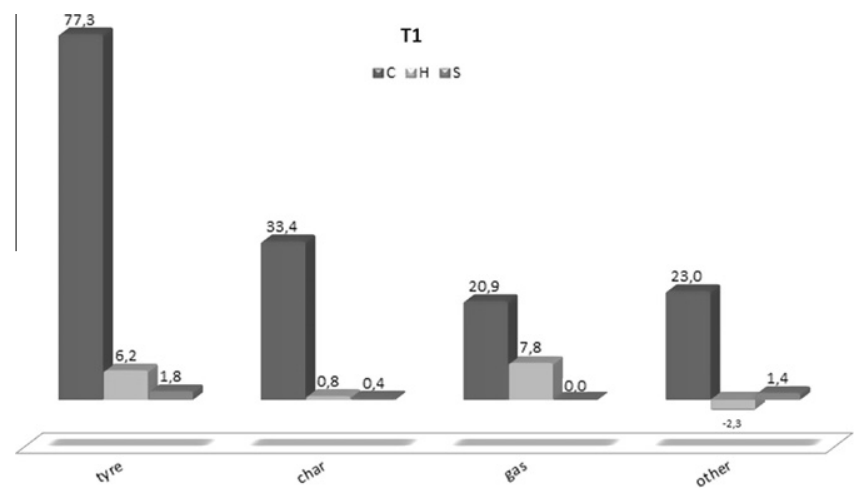

Fig. 5a. T1SGTy element mass balance.

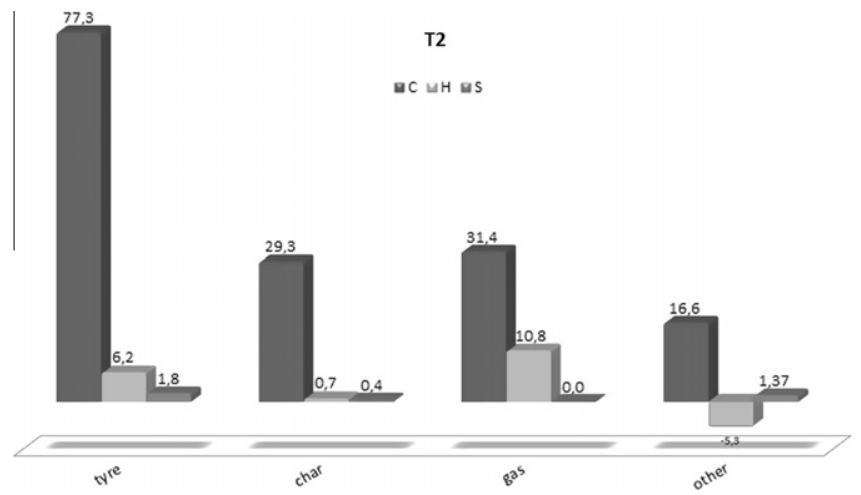

Fig. 5b. T2SGTy element mass balance.

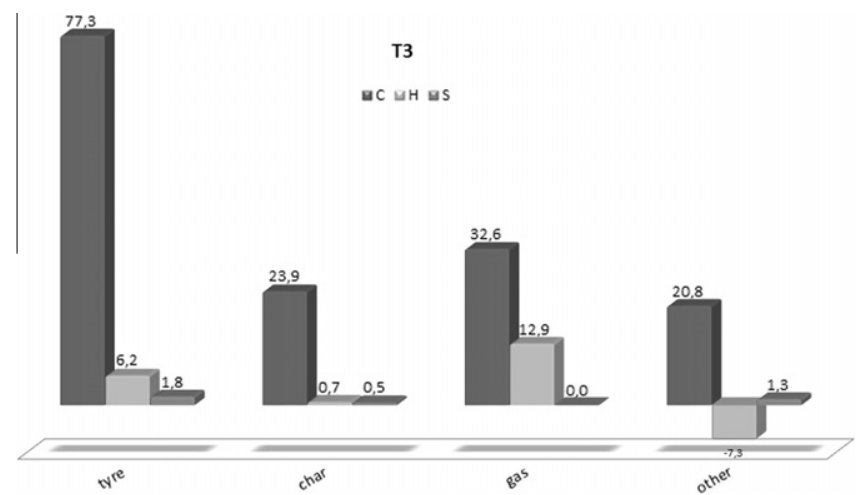

Fig. 5c. T3SGTy element mass balance.

carbon accordingly with the yields. Sulfur, mainly released as COS (Kagann, 1982), is almost concentrated in the volatile fraction (near 78\%); the amount is nearly constant with the temperature.

\section{Conclusions}

In the present work, the steam gasification of waste tyre was performed in a series of trials, by varying the process temperature within the range of $850-1000^{\circ} \mathrm{C}$, in order to evaluate the influence of the processing temperature on the properties of the products.

The data show that the process seems promising in view of obtaining a good quality syngas, indicating that a higher temperature results in a higher syngas production ( $86 \mathrm{wt} \%$ ). The syngas yield grows mainly against the condensable fraction, indicating an increase of the secondary cracking reactions in the vapor phase; moreover the char yield progressively decreases, due to the enhancement of solid-gas phase reactions with the temperature. In comparison with the biomass gasification, conducted at the same process conditions, an appreciable presence of liquid fraction (ranging from 27 to $5 \mathrm{wt} \%$ ) is registered in the considered temperature range; in this regard, the process could be improved through the application of a catalytic tar reforming step. It is important to remark that a large amount of soot was produced during the tests, which was appreciably reduced only at high temperature $\left(1000^{\circ} \mathrm{C}\right)$; consequently, to prevent the plugging of the pipes, a severe filtration with ceramic wool was necessary, which rendered extremely difficult the separation between tar and soot.

When all the operational parameters are held constant, the temperature definitely affects the gas composition, in favor of a higher hydrogen production at higher temperature (up to $65 \% \mathrm{v} /$ v) with respect to the hydrocarbon abundance; furthermore the syngas calorific value seems to be comparable to natural gas. The adopted operating conditions allow to obtain an appreciable amount of char, whose high carbon content suggest its further exploitation both as activated carbon (after the proper activation process) and as carbon source for synthesis reactions.

\section{Acknowledgements}

This study was supported by the Seventh Framework Programme (FP7) 2007-2013, in the frame of the TyGRe Project (Contract No. 226549). The author would like to acknowledge Mr. Nicolino Pasquale for his precious support for the development of the experimental activities.

\section{References}

Belgiorno, V., De Feo, G., Della Rocca, Napoli, R.M.A., 2003. Energy from gasification of solid wastes. Waste Manage. 23, 1-15.

Boroson, M.L., Howard, J.B., Longwell, J.P., Peters, W.A., 1989. Heterogeneous cracking of wood pyrolysis tars over fresh wood char surfaces. Energy Fuels 3, $735-740$.

Braekman-Danheux, C., D'haeyere, A., Fontana, A., Laurent, P., 1998. Upgrading of waste derived solid fuel by steam gasification. Fuel 77 (1/2), 55-59.

Bridgwater, A.V., 2003. Renewable fuels and chemicals by thermal processing of biomass. Chem. Eng. J. 91, 87-102.

Chaudhari, S.T., Bej, S.K., Bakhshi, N.N., Dalai, A.K., 2001. Steam gasification of biomass-derived char for the production of carbon monoxide-rich synthesis gas. Energy Fuels 15, 736-742.

Chaudhari, S.T., Dalai, A.K., Bakhshi, N.N., 2003. Production of hydrogen and/or syngas $\left(\mathrm{H}_{2}+\mathrm{CO}\right)$ via steam gasification of biomass-derived chars. Energy Fuels 17, 1062-1067.

Donatelli, A., Iovane, P., Molino, A., 2010. High energy syngas production by waste tyres steam gasification in a rotary kiln pilot plant. Experimental and numerical investigations. Fuel 89, 2721-2728.

Encinar, JM., Gonzalez, JF., Gonzalez, JF., 2002. Steam gasification of Cynara chardunculus L.: influence of variables. Fuel Process. Technol. 27, 27-43.

European Tyre Recycling Association (ETRA), Introduction to Tyre Recycling, 2008.

Franco, A., Giannini, N., 2005. Perspectives for the use of biomass as fuel in combined cycle power plants. Int. J. Thermal. Sci. 44, 163-177.

Galvagno, S., Casu, S., Casabianca, T., Calabrese, A., Cornacchia, G., 2002. Pyrolysis process for the treatment of scrap tyres: preliminary experimental results. Waste Manage. 22, 917-923.

Galvagno, S., Casu, S., Casciaro, G., Martino, M., Russo, A., Portofino, S., 2006. Steam gasification of refuse-derived fuel (RDF): influence of process temperature on yield and product composition. Energy Fuels 20, 2284-2288. 
678

S. Portofino et al./Waste Management 33 (2013) 672-678

Galvagno, S., Casu, S., Martino, M., Di Palma, E., Portofino, S., 2007. Thermal and kinetic study of tyre waste pyrolysis via TG-FTIR-MS analysis. J. Therm. Anal. Calorim. 88, 1-8.

Galvagno, S., Casciaro, G., Casu, S., Martino, M., Mingazzini, M., Russo, A., Portofino, S., 2009. Steam gasification of tyre waste, poplar, and refuse-derived fuel: a comparative analysis. Waste Manage. 29, 678-689.

González, J.F., Encinar, J.M., González-Garcýa, C.M., Sabio, E., Ramiro, E., Canito, J.L., Ganán, J., 2006. Preparation of activated carbons from used tyres by gasification with steam and carbon dioxide. Appl. Surf. Sci. 252, 5999-6004.

Kagann, R.H., 1982. Infrared absorption intensities for OCS. J. Mol. Spectrosc. 94, 192-198.

Kiran, N., Ekinci, E., Snape, C.E., 2000. Recycling of plastic wastes via pyrolysis. Resour. Conserv. Recycl. 29, 273-283.

Ko, D.C.K., Mui, E.L.K., Lau, K.S.T., McKay, G., 2004. Production of activated carbons from waste tire - process design. Waste Manage. 24, 875-888.

Leung, D.Y.C., Wang, C.L., 1998. Kinetic study of scrap tyre pyrolysis and combustion. J. Anal. Appl. Pyrol. 45, 153-169.

Leung, D.Y.C., Yin, X.L., Zhao, Z.L., Xu, B.Y., Chen, Y., 2002. Pyrolysis of tire powder: influence of operation variables on the composition and yields of gaseous product. Fuel Process. Technol. 79, 141-155.

Lin, S., Harada, M., Suzuki, Y., Datano, H., 2004. Continuous experiment regarding hydrogen production by coal/CaO reaction with steam (I) gas products. Fuel 83 , 869-874.

Lobachyov, K.V., Richter, H.J., 1998. An advanced integrated biomass gasification and molten fuel cell power system. Energy Convers. Manage. 39 (16-18), 19311943.

Malkow, T., 2004. Novel and innovative pyrolysis and gasification technologies for energy efficient and environmentally sound MSW disposal. Waste Manage. 24 53-79.

Mayoral, M.C., Izquierdo, M.T., Andrès, J.M., Rubio, B., 2001. Different approaches to proximate analysis by thermogravimetry analysis. Termochim. Acta 370, 91-97.

McKendry, P., 2002. Energy production from biomass (part 2): conversion technologies. Bioresour. Technol. 84, 47-54.

Morf, P., Hasler, P., Nussbaumer, T., 2002. Mechanism and kinetics of homogeneous secondary reactions of tar from continuous pyrolysis of wood chips. Fuel 81, $843-853$.
Morris, M., Waldheim, L., 1998. Energy recovery from solid waste fuels using advanced gasification technology. Waste Manage. 18, 557-564.

Mui, E.L.K., Ko, D.C.K., McKay, G., 2004. Production of active carbons from waste tyres--a review. Carbon 42, 2789-2805.

Nakagawa, K., Tamon, H., Suzuki, T., Nagano, S., 2002. Preparation and characterization of activated carbons from refuse derived fuel (RDF). J. Porous Mater. 9, 25-33.

Portofino, S., Casu, S., Iovane, P., Russo, A., Martino, M., Donatelli, A., Galvagno, S., 2011. Optimizing $\mathrm{H}_{2}$ production from waste tyres via combined steam gasification and catalytic reforming. Energy Fuels 25 (5), 2232-2241.

Rodriguez-Reinoso, F., Molina-Sabio, M., Gonzalez, M.T., 1995. The use of steam and $\mathrm{CO}_{2}$ as activating agents in the preparation of activated carbons. Carbon 33, 1523.

Sharma, V.K., Mincarini, M., Fortuna, F., Cognini, F., Cornacchia, G., 1998. Disposal of waste tyres for energy recovery and safe environment - a review. Energy Convers. Manage. 39 (5/6), 511-528.

Sułkowski, W.W., Danch, A., Moczyński, M., Radoń, A., Sułkowska, A., Borek, J., 2004. Thermogravimetric study of rubber waste-polyurethane composites. J. Therm. Anal. Cal. 78, 905.

Sullivan, J.D., Maier, C.G., Ralson, O.C., 1927. Passage of solid particles through rotary cylindric kilns. US Bur. Mines Tech. Pap. 384, 1-42.

Turn, S., Kinoshita, C., Zhang, Z., Ishimura, D., Zhou, J., 1998. An experimental investigation of hydrogen production from biomass gasification. Int. J. Hydrogen Energy 23 (8), 641-648.

Wei, L.G., Xu, S., Zhang, L., Liu, C., Zhu, H., Liu, S., 2007. Steam gasification of biomass for hydrogen-rich gas in a free-fall reactor. Int. J. Hydrogen Energy 32, 24-31.

Williams, P.T., Besler, S., 1995. Pyrolysis - thermogravimetric analysis of tyres and tyre components. Fuel 74, 1277-1283.

Wu, W., Kawamoto, K., Kuramochi, H., 2006. Hydrogen-rich synthesis gas production from waste wood via gasification and reforming technology for fuel cell application. J. Mater. Cycles Waste Manage. 8, 70-77.

Zabaniotou, A.A., Stavropoulos, G., 2003. Pyrolysis of used automobile tires and residual char utilization. J. Anal. Appl. Pyrol. 70, 711-722. 